\title{
Population genetic structure of the major malaria vector Anopheles darlingi (Diptera: Culicidae) from the Brazilian Amazon, using microsatellite markers
}

\author{
Vera Margarete Scarpassa/ ${ }^{+}$, Jan E Conn*
}

Coordenação de Pesquisas em Entomologia, Instituto Nacional de Pesquisas da Amazônia, Av. André Araújo 2936, 69011-970

Manaus, AM, Brasil * Griffin Laboratory, Wadsworth Center, New York State Department of Health, Slingerlands, NY, US

The population genetic structure of Anopheles darlingi, the major human malaria vector in the Neotropics, was examined using seven microsatellite loci from nine localities in central and western Amazonian Brazil. High levels of genetic variability were detected (5-25 alleles per locus; $\left.H_{E}=0.519-0.949\right)$. There was deviation from Hardy-Weinberg Equilibrium for 59.79\% of the tests due to heterozygote deficits, while the analysis of linkage disequilibrium was significant for only two of 189 (1.05\%) tests, most likely caused by null alleles. Genetic differentiation $\left(F_{S T}=0.001-0.095 ; \mathrm{Nm}=4.7-363.8\right)$ indicates that gene flow is extensive among locations $\leq 152 \mathrm{~km}$ apart (with two exceptions) and reduced, but not absent, at a larger geographic scale. Genetic and geographic distances were significantly correlated $\left(R^{2}=0.893, P<0.0002\right)$, supporting the isolation by distance (IBD) model. The overall estimate of Ne was 202.4 individuals under the linkage disequilibrium model, and $\infty$ under the heterozygote excess model. Analysis of molecular variance showed that nearly all variation $(\sim 94 \%)$ was within sample locations. The UPGMA phenogram clustered the samples geographically, with one branch including 5/6 of the state of Amazonas localities and the other branch the Acre, Rondonia, and remaining Amazonas localities. Taken together, these data suggest little genetic structure for An. darlingi from central and western Amazonian Brazil. These findings also imply that the IBD model explains nearly all of the differentiation detected. In practical terms, populations of An. darlingi at distances $\leq 152 \mathrm{~km}$ should respond similarly to vector control measures, because of high gene flow.

Key words: Anopheles darlingi - malaria vector - microsatellites - population genetics - Brazil

In Brazil after 1970, malaria was restricted to the Amazon Region, where currently more than $99 \%$ of all malaria cases are reported. In the 1980s in the Amazon, there was a progressive increase in malaria cases, as a result of extensive migration of human populations, deforestation, highway construction, uncoordinated settlements, hydroelectric dams, pipelines, and gold-mining camps. These factors affected the distribution and density of the major malaria vector Anopheles darlingi resulting in an increased burden of malaria in Amazonian Brazil (Charlwood 1996, Tadei et al. 1998, Gil et al. 2003). In 1999 more than 637,000 cases of malaria were reported, followed by a reduction for the three next years, presumably due to the intensification of malaria control programs (Funasa 2002); however, in last few years the malaria indices are on the rise again. Of the nine states that constitute the Amazon Region, Amazonas, Pará, and Rondônia showed the highest malaria incidence (together

Financial support: Ministério da Ciência e Tecnologia/Inpa, Brazil, National Institutes of Health (AI 40116 and AI R0154139 to JEC). This research was part of a Post-Doctoral fellowship of the first author undertaken at Conn's Lab in the Wadsworth Center, Albany, NY, US.

+ Corresponding author: vera@inpa.gov.br

Received 6 February 2007

Accepted 18 April 2007 they represent $76 \%$ of all cases recorded) with infection rates of $78.6 \%$ for Plasmodium vivax and $21.40 \%$ for $P$. falciparum (Funasa 2002, WHO 2005).

In the state of Amazonas in particular, the spread of the areas of malaria transmission, including historically low prevalence areas, has been documented. For example, in 2003, in Manaus, the state capital, an increase of $\sim 250 \%$ of malaria cases was reported compared with 2002, a historically high index. This index has been attributed to especially high temperature and humidity in the tropical forest, which offers favorable conditions for breeding and longevity of vector mosquitoes; environmental variation such as changes in rainy and dry seasons; social factors, population movement to the periphery of Manaus followed by deforestation; and uncoordinated settlements and precarious dwellings, providing contact between humans and vectors (Tadei et al. 1998, MS 2003, Susam/Devis 2004, WHO 2005).

An. darlingi is the major malaria vector in Brazil (Rachou 1958) and the most anthropophilic and efficient malaria vector in the Brazilian Amazon (Deane et al. 1948, Tadei et al. 1998, Gil et al. 2003). It is also a significant vector in other countries of its distribution such as Colombia, Peru, and Suriname (Rozendaal 1990, Olano et al. 2001, Vittor et al. 2006).

Because of its importance as a human malaria vector, geographic populations of An. darlingi have been the subject of several studies. Polytene chromosome analysis revealed high polymorphism in An. darlingi, with fixed inversions between samples from Southeast- 
ern and Northern Brazil, and a high frequency of heterozygote inversions detected in Northern Brazil (Kreutzer et al. 1972, Tadei et al. 1982). Subsequently, other population studies of An. darlingi have revealed high levels of genetic variability and low to moderate heterogeneity with a wide array of markers (Steiner et al. 1982, Rosa-Freitas et al. 1992, Freitas-Sibajev et al. 1995, Santos et al. 1999, Malafronte et al. 1999, Mirabello \& Conn 2006, González et al. 2007). However, a study conducted near the city of Iquitos, Peru, detected high homogeneity in nine populations, using random amplified polymorphic DNA-polymerase chain reaction (RAPD-PCR) (Pinedo-Cancino et al. 2006). Much of the variability detected in An. darlingi could be related to an adaptive strategy to exploit distinctive ecological niches within its extensive range (Kreutzer et al. 1972, Tadei et al. 1982, 1998) while the population structure and differentiation may be explained by differences in the effective population size, patterns of gene flow and historical and recent colonization events across its range.

The vast geographic distribution of An. darlingi from Southern Mexico to Northern Argentina (Linthicum 1988), as well as significant differences between populations documented by polytene chromosome (Kreutzer et al. 1972), isozyme (Steiner et al. 1982) and behavioral (revision in Rosa-Freitas et al. 1992) studies have led to the hypothesis of a species complex (Charlwood 1996). This hypothesis was rejected by Manguin et al. (1999) based on results of a multi-marker study (morphology, isozymes, ITS2-internal transcribed spacer two, and RAPD) that included samples from much of its range. Recently, a study based on mitochondrial DNA COI sequences detected a significant genetic division between Central America plus NW Colombia, and the rest of South America (Mirabello \& Conn 2006) and microsatellite data also detected significant differentiation across the eastern Amazonian region (Conn et al. 2006).

The aims of the present study were to estimate genetic variability and population structure and to infer the extent of gene flow among nine populations of $A n$. darlingi from central and western Brazilian Amazon, using seven dinucleotide microsatellite loci.

\section{MATERIALS AND METHODS}

Mosquito collection -The specimens of An. darlingi were collected in Amazonian Brazil from March 1998 to August 2002. The samples were from the municipality of Acrelândia (MAC), state of Acre; Porto Velho city (PVE), and municipality of São Miguel (SMI), both in the state of Rondônia; and Coari (COA), Novo Airão (NAI), Castanho (CAS), Puraquequara (PUR), Ramal do Brasileirinho (RBR), and Bancrévea (BAN), all in the state of Amazonas (Table I, Fig. 1). The latter three localities are situated on the periphery of Manaus, separated by about 10 to $19 \mathrm{~km}$. PUR and RBR are east of Manaus and nearest to it; BAN, to the north, is slightly farther away. The two localities, PVE and SMI from Rondônia are separated by about $16 \mathrm{~km}$, and they are on opposite sides of the Madeira River. The female mosquitoes were captured using human landing catches and resting on cattle corrals or on vegetation near human dwellings from 18:30 to 21:00 h. The standard human landing catch protocol in use in the Brazilian localities during the collection period (1998-2002) was reviewed and approved by the Institutional Review Board of the University of Vermont, US. After capture, the mosquitoes were transported to the Instituto Nacional de Pesquisas da Amazônia (Inpa), in Manaus, identified using the taxonomic key of Faran and Linthicum (1981), and immediately preserved in ethanol $95 \%$ or stored at $-80^{\circ} \mathrm{C}$, until analysis. For COA, both wild-caught females and offspring $\left(F_{1}\right)$ were used. All localities are in endemic malaria areas.

Microsatellite analysis - DNA was extracted from individual whole mosquitoes as described in Sambrook and Russel (2001). Eight microsatellite loci designed according to Conn et al. (2001) were used in the analyses and are as follow: $A D C 01, A D C 02, A D C 28, A D C 107$, $A D C 110, A D C 137, A D C 138$, and $A D C 29$. The same sample size was used for the eight loci; the $A D C 107$ locus, however, failed to amplify many individuals in all the samples after two attempts, even though these individuals were amplified for the remaining loci. Also, in the few individuals that did yield a PCR product, an excessive number of genotypes homozygous for different alleles were observed during the genotyping. Therefore, the $A D C 107$ locus was excluded from the analyses.

The PCR reactions were prepared containing 10 pmols of each primer, 1/100th of the genomic DNA, puRe Taq ${ }^{\mathrm{TM}}$ Ready TO GO ${ }^{\mathrm{TM}}$ PCR Beads, and distilled water to complete the final volume of $12 \mu$. The forward primer of each primer pair was labelled with a fluorescent dye (6FAM, HEX or TET, Applied Biosystems, Foster City, CA). DNA amplifications were carried out on a PTC-200 thermal cycler (MJ Research, Waltham, MA) as described in Conn et al. (2001). PCR products were then checked by electrophoresis in $1.5 \%$ agarose gels. The reactions for automated sequencing were carried out as follows: each PCR reaction (1.5 $\mu$ l aliquot) was prepared using standard protocols (Applied Biosystems) and analyzed on an ABI Prism 377 DNA Sequencer (Applied Biosystems). Gels were analyzed, and project and sample files were generated using $A B I$ GENESCAN software, version 3.1 (Applied Biosystems). Subsequently, allele sizes were scored and compared with internal size standards using GENOTYPER software, version 2.6 (Applied Biosystems).

Statistical analyses - The analyses were performed using ARLEQUIN software, version 3.01 (Excoffier et al. 2006). The genetic variability was estimated using frequency of alleles, departure from Hardy-Weinberg Equilibrium (HWE), observed and expected heterozygosity ( $H_{\mathrm{O}}$ and $H_{\mathrm{E}}$, respectively) per locus, linkage disequilibrium and AMOVA. For the loci that were not in HWE, frequencies of null alleles $(r)$ were calculated using the following expression: $r=\left(H_{\mathrm{E}}-H_{\mathrm{O}}\right) /\left(H_{\mathrm{E}}+H_{\mathrm{O}}\right)$. The inbreeding coefficient $F_{\text {IS }}$ was calculated for all loci using the expression: $F_{\mathrm{IS}}=H_{\mathrm{E}}-H_{\mathrm{O}} / H_{\mathrm{E}}$ (Wright 1965).

The pairwise genetic distances, based on the $F_{\mathrm{ST}}$ statistic, and isolation by distance (IBD) test were calcu- 


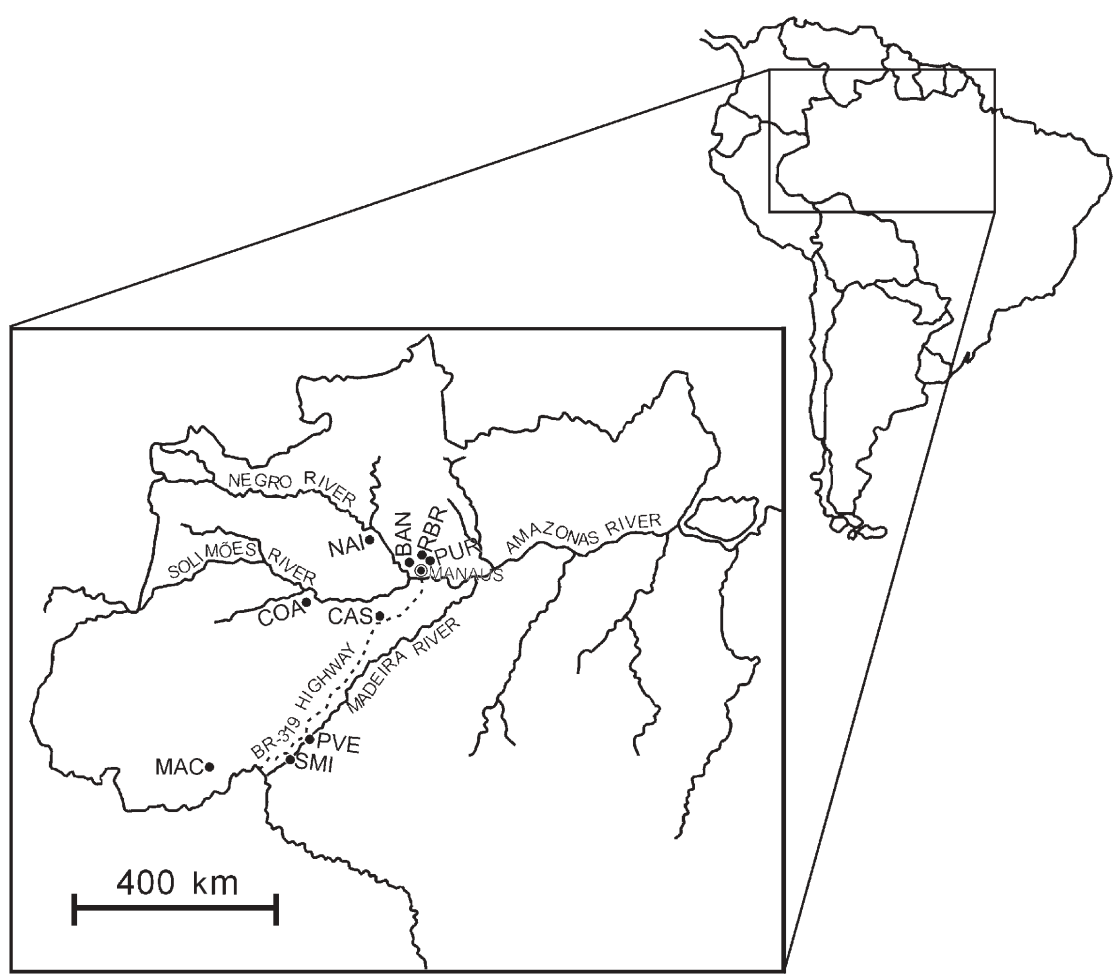

Fig. 1: collection sites of Anopheles darlingi. Abbreviations of localities are in Table I.

TABLE I

Localities sampled for Anopheles darlingi from central and western Amazonian Brazil

\begin{tabular}{|c|c|c|c|c|c|}
\hline Location code & Locality & State & Coordinates & Samples size & Collection date \\
\hline MAC & Municipality of Acrelândia & Acre & $10^{\circ} 08^{\prime} \mathrm{S}, 67^{\circ} 32^{\prime} \mathrm{W}$ & 23 & August, 2002 \\
\hline PVE & Porto Velho City & Rondônia & $08^{\circ} 45^{\prime} \mathrm{S}, 63^{\circ} 53^{\prime} \mathrm{W}$ & 45 & April, 2002 \\
\hline SMI & Municipality of São Miguel & Rondônia & $08^{\circ} 36^{\prime} \mathrm{S}, 63^{\circ} 49^{\prime} \mathrm{W}$ & 46 & April, 2002 \\
\hline $\mathrm{COA}$ & Coari & Amazonas & $04^{\circ} 05^{\prime} \mathrm{S}, 63^{\circ} 08^{\prime} \mathrm{W}$ & 44 & June, 2001 \\
\hline NAI & Novo Airão & Amazonas & $01^{\circ} 56^{\prime} \mathrm{S}, 61^{\circ} 22^{\prime} \mathrm{W}$ & 45 & December, 1998 \\
\hline CAS & Castanho, BR-319 HW & Amazonas & $03^{\circ} 49^{\prime} \mathrm{S}, 60^{\circ} 21^{\prime} \mathrm{W}$ & 47 & June, 1998 \\
\hline PUR & Puraquequara $^{a}$ & Amazonas & $03^{\circ} 08^{\prime} \mathrm{S}, 60^{\circ} 01^{\prime} \mathrm{W}$ & 48 & March, 1998 \\
\hline RBR & Ramal do Brasileirinho $^{a}$ & Amazonas & $03^{\circ} 01^{\prime} \mathrm{S}, 59^{\circ} 57^{\prime} \mathrm{W}$ & 47 & July, 1998 \\
\hline BAN & Bancrévea $^{a}$ & Amazonas & $02^{\circ} 59^{\prime} \mathrm{S}, 60^{\circ} 04^{\prime} \mathrm{W}$ & 32 & April, 1998 \\
\hline
\end{tabular}

$a$ : three localities on periphery of Manaus; HW: Highway

lated using ARLEQUIN software. The $F_{\mathrm{ST}}$ (Weir \& Cockerham 1984) assumes the infinite alleles model (IAM) and was calculated based on the absolute frequencies of alleles. The significance of $F_{\mathrm{ST}}$ was determined by permuting genotypes between localities $(10,100$ permutations). We used the $F_{\mathrm{ST}}$ statistic only (not $R_{\mathrm{ST}}$ ) because $F_{\mathrm{ST}}$ is considered more reliable when fewer than 20 microsatellite loci are analyzed (Gaggiotti et al. 1999). The number of migrants per population per generation $(\mathrm{Nm}=$ migration indices $)$ between localities was estimated from pairwise $F_{\mathrm{ST}}$ values. IBD was estimated using the correlation between genetic and geographic distances by the regression of $F_{\mathrm{ST}} / 1-F_{\mathrm{ST}}$ on the natural logarithm (In) of straight-line geographical distance. The significance level was tested using 10,000 permutations.

Effective population size $(\mathrm{Ne})$ was calculated using NeEstimator software, version 1.3 (Peel et al. 2004), based on the linkage disequilibrium (LD) and heterozygote excess (HE) models. These estimates were calculated from the deviation of expected compared to observed degree of linkage disequilibrium and from the excess of heterozygotes in the sample compared to the proportion predicted under HWE. The genetic relationships between the populations were also assessed by a UPGMA phenogram using PAUP* software, version 4.0 (Swofford 2003). When multiple tests were performed, the nominal significance level $(P<0.05)$ was adjusted using the sequential Bonferroni procedure (Holm 1979). 


\section{RESULTS}

A total of 377 individuals was analyzed (Table I). All loci revealed high levels of polymorphism, with a total of 105 alleles, and there were 5 to 25 alleles per locus in the nine populations (Table II). The ADCO1 locus exhibited the largest allele number (from 18-25), whereas the $A D C 28$ locus had the fewest (from 5-11). All western samples, from MAC, PVE, and SMI (states of Acre and Rondônia) had the highest allele number and mean expected heterozygosity levels $\left(H_{\mathrm{E}}=0.855 ; 0.800\right.$; 0.781 , respectively) compared with the samples from state of Amazonas.

No locus was in HWE for all the samples assayed (Table II). Thirty-two of the $63(50.79 \%)$ comparisons exhibited significant departures from HWE after sequential Bonferroni correction $(P<0.05)$, due to heterozy-

TABLE II

Estimates of genetic variability of Anopheles darlingi from central and western Amazonian Brazil

\begin{tabular}{|c|c|c|c|c|c|c|c|c|c|}
\hline Locus & $\begin{array}{c}\text { MAC } \\
2 \mathrm{~N}=46\end{array}$ & $\begin{array}{c}\mathrm{PVE} \\
2 \mathrm{~N}=90\end{array}$ & $\begin{array}{c}\text { SMI } \\
2 \mathrm{~N}=92\end{array}$ & $\begin{array}{c}\mathrm{COA} \\
2 \mathrm{~N}=88\end{array}$ & $\begin{array}{c}\text { NAI } \\
2 \mathrm{~N}=90\end{array}$ & $\begin{array}{c}\text { CAS } \\
2 \mathrm{~N}=94\end{array}$ & $\begin{array}{c}\text { PUR } \\
2 \mathrm{~N}=96\end{array}$ & $\begin{array}{c}\text { RBR } \\
2 n=94\end{array}$ & $\begin{array}{c}\text { BAN } \\
2 \mathrm{~N}=64\end{array}$ \\
\hline \multicolumn{10}{|l|}{$A D C 01$} \\
\hline No. alleles & 20 & 24 & 25 & 18 & 23 & 21 & 21 & 20 & 21 \\
\hline$H_{\mathrm{O}}$ & 0.783 & 0.800 & 0.844 & 0.795 & 0.841 & 0.822 & 0.896 & 0.739 & 0.781 \\
\hline$H_{\mathrm{E}}$ & 0.949 & 0.947 & 0.938 & 0.894 & 0.919 & 0.934 & 0.924 & 0.897 & 0.920 \\
\hline$r^{\mathrm{L}}$ & - & 0.08 & - & - & - & - & - & 0.09 & 0.08 \\
\hline$F_{\text {IS }}$ & 0.175 & 0.155 & 0.100 & 0.111 & 0.085 & 0.120 & 0.030 & 0.180 & 0.150 \\
\hline \multicolumn{10}{|l|}{$A D C 02$} \\
\hline No. alleles & 11 & 12 & 14 & 9 & 8 & 8 & 8 & 7 & 9 \\
\hline$H_{\mathrm{O}}$ & 0.348 & 0.600 & 0.556 & 0.465 & 0.378 & 0.415 & 0.271 & 0.213 & 0.188 \\
\hline$H_{\mathrm{E}}$ & 0.773 & 0.752 & 0.799 & 0.771 & 0.771 & 0.686 & 0.756 & 0.733 & 0.816 \\
\hline$r^{\mathrm{E}}$ & 0.38 & - & 0.18 & 0.25 & 0.34 & 0.25 & 0.47 & 0.55 & 0.62 \\
\hline$F_{\mathrm{IS}}$ & 0.550 & 0.202 & 0.304 & 0.397 & 0.510 & 0.395 & 0.642 & 0.709 & 0.770 \\
\hline \multicolumn{10}{|l|}{$A D C 28$} \\
\hline No. alleles & 11 & 10 & 6 & 7 & 8 & 6 & 6 & 5 & 6 \\
\hline$H_{\mathrm{O}}$ & 0.652 & 0.750 & 0.601 & 0.682 & 0.467 & 0.340 & 0.435 & 0.149 & 0.375 \\
\hline$H_{\mathrm{E}}$ & 0.866 & 0.789 & 0.678 & 0.661 & 0.586 & 0.668 & 0.546 & 0.519 & 0.528 \\
\hline$r^{\mathrm{L}}$ & 0.14 & - & - & - & - & 0.32 & 0.11 & 0.55 & 0.17 \\
\hline$F_{\mathrm{IS}}$ & 0.247 & 0.049 & 0.114 & -0.032 & 0.203 & 0.491 & 0.203 & 0.713 & 0.290 \\
\hline \multicolumn{10}{|l|}{$A D C 110$} \\
\hline No. alleles & 12 & 12 & 10 & 9 & 8 & 8 & 9 & 7 & 6 \\
\hline$H_{\mathrm{O}}$ & 0.773 & 0.933 & 0.733 & 0.614 & 0.622 & 0.681 & 0.808 & 0.696 & 0.719 \\
\hline$H_{\mathrm{E}}$ & 0.902 & 0.854 & 0.838 & 0.850 & 0.737 & 0.815 & 0.809 & 0.812 & 0.822 \\
\hline$r^{\mathrm{D}}$ & - & - & - & 0.16 & - & - & - & - & - \\
\hline$F_{\mathrm{IS}}$ & 0.143 & -0.092 & 0.125 & 0.278 & 0.156 & 0.164 & 0.001 & 0.143 & 0.125 \\
\hline \multicolumn{10}{|l|}{$A D C 137$} \\
\hline No. alleles & 13 & 12 & 13 & 10 & 9 & 10 & 11 & 11 & 9 \\
\hline$H_{\mathrm{O}}$ & 0.869 & 0.711 & 0.783 & 0.659 & 0.644 & 0.787 & 0.659 & 0.723 & 0.750 \\
\hline$H_{\mathrm{E}}$ & 0.889 & 0.884 & 0.848 & 0.865 & 0.818 & 0.846 & 0.864 & 0.885 & 0.852 \\
\hline$r$ & - & - & - & 0.13 & - & - & 0.13 & - & - \\
\hline$F_{\text {IS }}$ & 0.022 & 0.196 & 0.077 & 0.238 & 0.213 & 0.070 & 0.237 & 0.183 & 0.120 \\
\hline \multicolumn{10}{|l|}{$A D C 138$} \\
\hline No. alleles & 8 & 12 & 11 & 8 & 7 & 9 & 7 & 9 & 6 \\
\hline$H_{\mathrm{O}}$ & 0.522 & 0.450 & 0.585 & 0.545 & 0.467 & 0.444 & 0.489 & 0.511 & 0.438 \\
\hline$H_{\mathrm{E}}$ & 0.853 & 0.895 & 0.881 & 0.782 & 0.680 & 0.708 & 0.694 & 0.723 & 0.768 \\
\hline$r$ & 0.24 & 0.33 & 0.20 & 0.18 & - & 0.23 & 0.17 & - & 0.27 \\
\hline$F_{\mathrm{IS}}$ & 0.388 & 0.497 & 0.336 & 0.303 & 0.313 & 0.373 & 0.295 & 0.293 & 0.430 \\
\hline \multicolumn{10}{|l|}{$A D C 29$} \\
\hline No. alleles & 12 & 18 & 14 & 9 & 9 & 11 & 8 & 10 & 9 \\
\hline$H_{\mathrm{O}}$ & 0.652 & 0.488 & 0.341 & 0.512 & 0.386 & 0.488 & 0.349 & 0.500 & 0.548 \\
\hline$H_{\mathrm{E}}$ & 0.875 & 0.809 & 0.883 & 0.711 & 0.700 & 0.757 & 0.558 & 0.719 & 0.738 \\
\hline$r^{\mathrm{E}}$ & - & 0.25 & 0.44 & - & 0.29 & 0.22 & 0.23 & 0.18 & - \\
\hline$F_{\text {IS }}$ & 0.255 & 0.397 & 0.614 & 0.280 & 0.448 & 0.355 & 0.374 & 0.304 & 0.257 \\
\hline $\begin{array}{l}\text { Mean } H_{\mathrm{E}} \\
( \pm \mathrm{SE})\end{array}$ & $\begin{array}{c}0.855 \\
(0.46)\end{array}$ & $\begin{array}{l}0.800 \\
(0.42)\end{array}$ & $\begin{array}{c}0.781 \\
(0.42)\end{array}$ & $\begin{array}{l}0.776 \\
(0.41)\end{array}$ & $\begin{array}{l}0.729 \\
(0.39)\end{array}$ & $\begin{array}{c}0.705 \\
(0.38)\end{array}$ & $\begin{array}{l}0.692 \\
(0.37)\end{array}$ & $\begin{array}{c}0.729 \\
(0.39)\end{array}$ & $\begin{array}{l}0.761 \\
(0.41)\end{array}$ \\
\hline
\end{tabular}

$\overline{H_{\mathrm{O}}}$ : observed heterozygosity; $H_{\mathrm{E}}$ : expected heterozygosity; $r$ : estimated frequency of null alleles. $F_{\mathrm{IS}}:$ inbreeding coefficient; $-:$ no significant heterozygote deficiency. The values in bold indicate disequilibrium in the loci according to Hardy-Weinberg Equilibrium, after adjustment by the sequential Bonferroni correction $(P<0.05)$. Abbreviations of localities are in Table I. 
gote deficiencies, and the inbreeding coefficient $\left(F_{\text {IS }}\right)$ was positive in most cases. The $A D C 110$ locus showed a significant departure from HWE for only one sample, whereas the $A D C 02$ and $A D C 138$ loci deviated from HWE for eight and seven samples, respectively. The PUR sample exhibited the highest number of loci deviating from HWE, which could be related to its lower gene diversity (0.692). In all samples, each locus failed to amplify for at least one specimen after two attempts, while the same specimen yielded PCR products for the remaining loci, strongly suggesting the presence of null alleles. Estimates of the frequency of null alleles are given in Table II. The ADCO2 locus, for example, showed a high frequency of both null alleles and $F_{\text {IS }}$ values, primarily in the three samples from Manaus and in the NAI samples. The ADC28 locus in the RBR sample and the $A D C 29$ locus in the SMI sample also showed high values (Table II).

Analysis of linkage disequilibrium was carried out to confirm whether the deviations from HWE withinsamples were due to Wahlund effect, inbreeding, selection or null alleles. Only two of $189(1.05 \%)$ of exact tests were significant for linkage disequilibrium $(P<$ 0.05 ), after sequential Bonferroni correction. The significant values were between the loci ADC29/ADC138 in the SMI sample and between the loci ADC110/ADC02 in the COA sample.

Significant genetic differentiation was observed for the most of the comparisons between localities $(P<$ 0.001 ), after the sequential Bonferroni correction (Table III). The average $F_{\mathrm{ST}}$ value over all loci was 0.044 , with a large range (0.001 to 0.095). As expected if the IBD model is supported, the $F_{\mathrm{ST}}$ values were not significant for those population pairs separated by the smallest geographic distances (i.e., 10-152 km). The exceptions are CAS-PUR and CAS-RBR where the geographic distances are 119 and $134 \mathrm{~km}$, respectively, but they are significantly differentiated $\left(F_{\mathrm{ST}}=0.020 ; 0.024 ; P<0.001\right)$. The highest genetic differentiation $\left(F_{\mathrm{ST}}=0.067-0.095\right)$ was found among samples from MAC and state of Amazonas that were farthest apart geographically, with corresponding $\mathrm{Nm}$ values of 4.7 to 6.9. This result indicates reduced gene flow among them. Within state of
Amazonas, COA was the most diverged $\left(F_{\mathrm{ST}}=0.047-\right.$ 0.056; $\mathrm{Nm}=8.4-10.1$ ), however between COA and PVE/ SMI (state of Rondônia), separated by greater geographic distances, the $F_{\mathrm{ST}}$ values were lower $\left(F_{\mathrm{ST}}=0.030\right.$, 0.024; $\mathrm{Nm}=16.2,20.0$; respectively).

In an AMOVA, the placement of COA (either grouped with the other samples from Amazonas or with the samples from Acre and Rondônia) made no significant difference (data not shown). Most of the total variance was explained at the within population level (94-95\%; $P$ $<0.001)$. Only $3-4 \%$ of the variance was attributable to between groups $(P<0.05)$, and about $2 \%$ was attributable to among populations within groups $(P<0.001)$. The Mantel test showed a significant positive correlation between geographic distances and $F_{\mathrm{ST}}$ values $\left(R^{2}=\right.$ $0.893 ; P<0.0002)$, indicating that most genetic differentiation can be explained by the IBD model.

Effective population size $(\mathrm{Ne})$ differed between two models employed (Table IV). Under the LD model, the average Ne was 202.4 individuals, with a $95 \%$ confidence interval of 186.1-220.8. Ne was lowest (83.0 individuals) in the COA sample and highest $(\infty)$ in the PVE sample. Under the HE model, $N$ e values were $\infty$ for all localities.

TABLE IV

Effective population size (Ne) in Anopheles darlingi, based on linkage disequilibrium (LD) and heterozygote excess (HE) models

\begin{tabular}{lcccc}
\hline Localities & LD & $95 \%$ CI & HE & $95 \%$ CI \\
\hline MAC & 191.1 & $81.3-\infty$ & $\infty$ & NA \\
PVE & $\infty$ & $505.7-\infty$ & $\infty$ & NA \\
SMI & 238.3 & $126.0-1383.1$ & $\infty$ & NA \\
COA & 83.0 & $57.5-139.2$ & $\infty$ & NA \\
NAI & 152.0 & $87.7-456.8$ & $\infty$ & NA \\
CAS & 501.2 & $149.5-\infty$ & $\infty$ & NA \\
PUR & 178.2 & $94.1-932.1$ & $\infty$ & NA \\
RBR & 469.6 & $145.2-\infty$ & $\infty$ & NA \\
BAN & 155.8 & $74.0-314153.3$ & $\infty$ & NA \\
\hline All localities & 202.4 & $186.1-220.8$ & $\infty$ & NA
\end{tabular}

CI: confidence interval; $\infty$ : infinity; NA: not applicable. Abbreviations of localities are in Table I.

TABLE III

Pairwise genetic distance $\left(F_{\mathrm{ST}}\right)$ for samples of Anopheles darlingi from central and western Amazonian Brazil

\begin{tabular}{|c|c|c|c|c|c|c|c|c|c|}
\hline Samples & MAC & PVE & SMI & $\mathrm{COA}$ & NAI & CAS & PUR & RBR & BAN \\
\hline IAC & - & 444 & 430 & 851 & 1129 & 1060 & 1173 & 1184 & 1180 \\
\hline PVE & $0.029 *(16.9)$ & - & 16 & 541 & 770 & 674 & 785 & 800 & 796 \\
\hline SMI & $0.024 *(20.0)$ & $0.006(81.9)$ & - & 555 & 777 & 685 & 800 & 814 & 811 \\
\hline $\mathrm{COA}$ & $0.070 *(6.5)$ & $0.030 *(16.2)$ & $0.024 *(20.0)$ & - & 296 & 296 & 378 & 389 & 378 \\
\hline NAI & $0.089 *(5.1)$ & $0.056 *(8.4)$ & $0.060 *(7.7)$ & $0.056 *(8.5)$ & - & 152 & 119 & 126 & 115 \\
\hline CAS & $0.067 *(6.9)$ & $0.036 *(13.4)$ & $0.044 *(10.9)$ & $0.047 *(10.1)$ & $0.016(31.4)$ & - & 119 & 134 & 130 \\
\hline $\begin{array}{l}\text { PUR } \\
\text { PUR }\end{array}$ & $0.095 *(4.7)$ & $0.056 *(8.4)$ & $0.060 *(7.7)$ & $0.056 *(8.4)$ & $0.003(156.4)$ & $0.020 *(2$ & - & 10 & \\
\hline RBR & $0.083 *(5.5)$ & $0.048 *(9.8)$ & $0.048 *(9.9)$ & $0.048 *(10.0)$ & $0.007(72.5)$ & $0.024 *(20.1)$ & $0.001(363.8)$ & - & \\
\hline BAN & $0.078 *(5.9)$ & $0.045^{*}(10.5)$ & $0.048 *(9.9)$ & $0.051 *(9.2)$ & $0.010(49.0)$ & $0.008(64.6)$ & $0.008(62.1)$ & $0.011(45.4)$ & \\
\hline
\end{tabular}

Approximate geographical distances in km are above diagonal; $F_{\mathrm{ST}}$ values are below diagonal. $*: P<0.001$, after sequential Bonferroni correction. $\mathrm{Nm}$ values are in parentheses. Abbreviations of localities are in Table I. 
The clusters in the UPGMA phenogram (Fig. 2) were much as expected, based on the IBD model, with COA (the most western of the Amazonas state localities) grouped with samples from Acre and Rondônia, and the five remaining samples from Amazonas state (more central) grouped together.

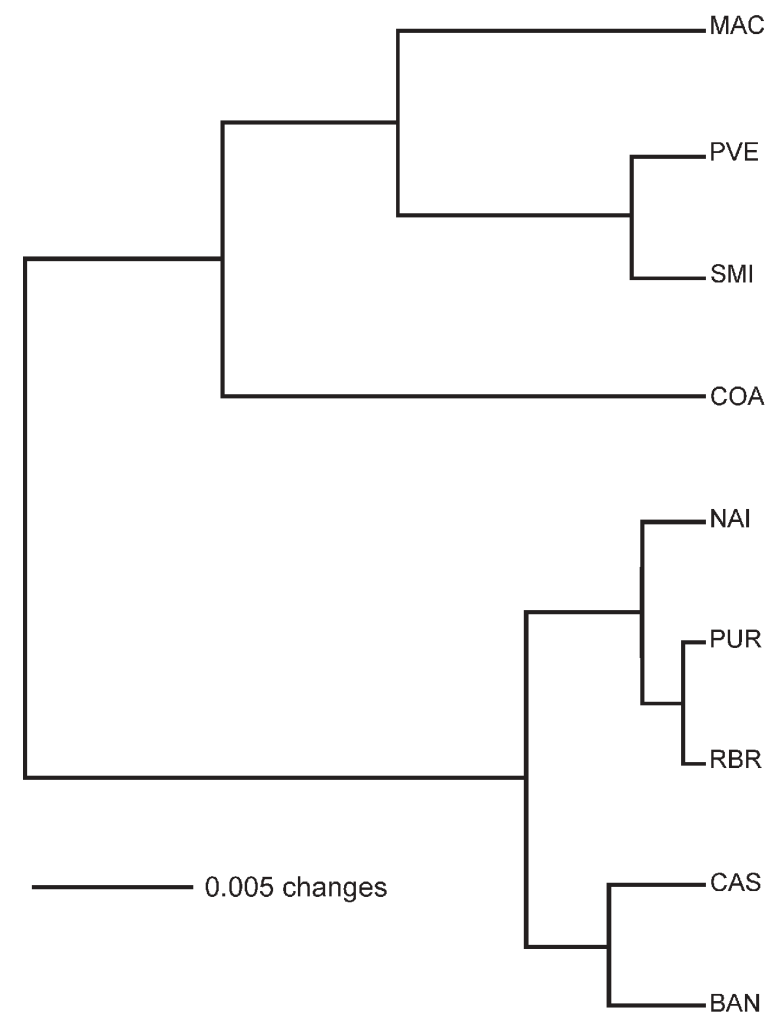

Fig. 2: unweighted pair group method (UPGMA) between samples of Anopheles darlingi, based on the pairwise $F_{S \mathrm{~T}}$ values. Abbreviations of localities are in Table I.

\section{DISCUSSION}

The microsatellite loci used in this study have not been physically mapped to the polytene chromosomes of An. darlingi, and therefore their location relative to inversions is unknown. If any are linked to chromosomal inversions, this may alter the interpretation of the data since neutrality cannot be assumed.

Microsatellite loci analyzed in An. darlingi from central and western Brazilian Amazon were highly polymorphic and found to be at least six-fold more variable than isozymes (Rosa-Freitas et al. 1992, Manguin et al. 1999, Santos et al. 1999). Compared with others microsatellite studies, the $H_{\mathrm{E}}$ values $(0.519-0.949)$ reported here are in the same range as those found for $A n$. darlingi from eastern Brazilian Amazon (Conn et al. 2006) and for other major malaria vectors, such as $A n$. gambiae s. s. in Africa (Lehmann et al. 1997) and $A n$. albimanus in Latin America (Molina-Cruz et al. 2004).

In this study, significant deviations for HWE were due to heterozygote deficits. These could be the result of the Wahlund effect (population subdivision), inbreed- ing, selection or null alleles. Linkage disequilibrium was absent in $98.95 \%$ of the exact tests; therefore, it is highly unlikely that the Wahlund effect or inbreeding, which affect the entire genome, could be the cause. Earlier studies of An. darlingi from central Amazonian Brazil using polytene chromosomes (Kreutzer et al. 1972, Tadei et al. 1982) and isozymes (Rosa-Freitas et al. 1992, Manguin et al. 1999) detected no suggested intra-populational differentiation making the Wahlund effect an unlikely explanation. Taken together, these observations strongly suggest the presence of null alleles in $A n$. darlingi of this study, as have been observed in $A n$. darlingi from eastern Brazilian Amazon (Conn et al. 2006), and in other microsatellite studies (Lehmann et al. 1997, Kamau et al. 1999).

Previous studies employing mtDNA (Freitas-Sibajev et al. 1995) and isozymes (Santos et al. 1999) reported higher divergences for An. darlingi from Manaus compared with other samples. Freitas-Sibajev et al. (1995) described small sequence divergence values among all samples analyzed, except for comparisons involving Manaus, where these values were within the lower range of interspecific genetic distances, as observed for members of the An. quadrimaculatus complex (discussed in Freitas-Sibajev et al. 1995). For isozymes analyses, although genetic homogeneity was found among the samples $(\mathrm{D}=0.011-0.024)$, those from Manaus were the most diverged (Santos et al. 1999). In the present study, the higher levels of heterozygote deficits detected in the samples up to $134 \mathrm{~km}$ from Manaus (NAI and CAS) and on the periphery of Manaus (especially, PUR and RBR) could be the result of a reduction of informativeness of these primers possibly due to a greater accumulation of different mutations in their flanking regions, that probably prevented PCR amplifications, resulting in a higher frequency of null alleles, and consequently higher levels of heterozygote deficits. We think the main reason for the presence of null alleles could be that the whole microsatellite library was constructed only of An. darlingi from Capanema (eastern Amazonian Brazil, Conn et al. 2001).

Genetic differentiation was low and not significant between populations separated by distances less than $152 \mathrm{~km}$, with two exceptions (CAS-PUR; CAS-RBR) and the $\mathrm{Nm}$ values suggest extensive gene flow among them. These results were similar to findings of low differentiation over a similar range of distances for $A n$. arabiensis in Cameroon (Wondji et al. 2005). In a study of nine populations of An. darlingi within $\sim 60 \mathrm{~km}$ of Iquitos (Peru), very low genetic structure was evident. The authors concluded that gene flow was the primary factor influencing structure (Pinedo-Cancino et al. 2006). Our data did not identify obvious genetic structure across the geographical scale up to $152 \mathrm{~km}$, perhaps due to the abundance (reflected in the Ne values: 152.0-501.2) and dispersal ability of these populations (reflected in the high gene flow), as a consequence of some combination of the following: high availability of breeding sites especially during the rainy season, complex environmental and social factors, and expansion of human activities. 
At the macrogeographic level, from 296 to $1184 \mathrm{~km}$, the data showed significant genetic differentiation in $A n$. darlingi, primarily between samples with greater distances, for example between MAC and the samples from Amazonas state. According to Slatkin (1987) genetic differentiation will be substantial if $\mathrm{Nm}<1$ but not if $\mathrm{Nm}>1$. Our results for these comparisons showed $\mathrm{Nm}$ values $>1$ (4.7 to 6.9), suggesting that gene flow is restricted but not absent, and probably prevented any diagnostic differences between them.

The AMOVA analysis indicated low variance between groups $(\sim 3 \%)$ and among populations within groups ( $2 \%$ ), consistent with IBD and comparable to results from An. gambiae s. s. (Kamau et al. 1999). Conn et al. (2006)'s data showed higher genetic differentiation, based on the $F_{\mathrm{ST}}$ (highest values $=0.1464-0.1841$ ) and hierarchic analysis (between groups $=\sim 12 \%$ ), indicating that populations of An. darlingi from eastern Brazilian Amazon are more genetically structured than $A n$. darling $i$ in the present study.

Likewise, the average Ne (202.4 individuals) in the present study was two-fold higher than that observed for An. darlingi from eastern Amazonian Brazil $(\mathrm{Ne}=92.4$, Conn et al. 2006) and for the other Neotropical malaria vector An. albimanus ( $\mathrm{Ne}=96$, Molina-Cruz et al. 2004). Considering each population separately in the present study, all $N$ e values were high under the LD model, except for COA. It is also possible that the large range of $N$ e values for all populations under LD $(83-\infty)$ could have contributed to the genetic differentiation such that the $F_{\mathrm{ST}}$ estimates at the greatest geographic distances were statistically significant, despite obvious gene flow (Donnelly et al. 2002).

In the sample from PVE, the Ne was $\infty$ under both models, which suggests a very high density of $A n$. darlingi locally. In the state of Amazonas, primarily in Manaus, the use of insecticidal fogging has intensified during the past ten years due to high malaria transmission indices; nevertheless, the Ne values for these populations (PUR, RBR, BAN; $N e=155.8-469.6$ ) show that despite frequent application of insecticides, large populations of An. darlingi are being maintained. This implies that insufficient levels of insecticide are currently being used (notwithstanding the highly complex environmental and social factors in this region). Another explanation could be that exclusively local interventions may result in the influx of mosquitoes from untreated neighborhood areas, resulting in operational failures and large population size again a short time after fogging. Also, the increase of An. darlingi population size could be due to other factors, such as the availability of breeding sites and city expansion in the form of uncoordinated settlements near forests. In addition, compared with 50 yr. ago (Deane et al. 1948) some populations of An. darlingi have changed their behavior, now being more exophilic and exophagic and/or leaving dwellings immediately after feeding (Tadei 1987, Charlwood 1996, Gil et al. 2003), making the use of indoor insecticide and other individual protection measures less effective. This complex situation suggests that integrated and coordinated local or regional control must be considered. For example, a concerted effort to identify suitable $A n$. darlingi breeding sites, particularly in proposed new settlements and discouraging people from living nearby, could be useful because An. darlingi does not seem to fly far to seek human bloodmeals if other mammal hosts are available (Zimmerman et al. 2006). In areas where people are already settled near breeding sites, another possibility might be the use of an environmentally acceptable insecticide, such as Bacillus sphaericus for aquatic stages (Rodrigues et al. 1998) combined with fogging for adults, focusing on the peak transmission time of the year. However, integrated malaria control also needs to take into account the proportion of asymptomatic malaria persons (Coura et al. 2006) and resistance to anti-malarial drugs (Vieira et al. 2004) in a given area to have any hope of success.

The low Ne observed for An. darlingi from COA may have magnified differentiation between this and the other Amazonas populations by genetic drift, a fundamental parameter influencing genetic population structure. Interestingly, this locality showed linkage disequilibrium between the ADC110/ADCO2 loci; nevertheless, its expected heterozygosity was high.

The large populations of An. darlingi reflected in the high $N$ e values may be contributing to an increase in gene flow among subpopulations, resulting in little genetic structure for An. darlingi from central and western Brazilian Amazon, a result similar to that found with the use of multi-markers (Manguin et al. 1999, Santos et al. 1999) and also similar to results from Iquitos, Peru, with the use RAPD marker (Pinedo-Cancino et al. 2006). A recent study with three populations from Colombia showed also little evidence of geographic separation between eastern and western from mountains Andes, with the use RAPD and AFLP (Amplified Fragment Length Polymorphism) markers (González et al. 2007).

Otherwise, the differences in population structure across Amazonian Brazil detected by microsatellite data, i. e., less structure and differentiation in central and western Brazilian Amazon compared with eastern Brazilian Amazon, are congruent with results using sequences of the nuclear white gene (L Mirabello \& JE Conn, unpublished observations). This differentiation in An. darlingi probably has its origin in regional Amazonian biogeography, which is far from homogeneous. The samples of An. darlingi collected in the present study and those from Conn et al. (2006) are along different major Amazon river systems (Negro, Solimões, Madeira, and mouth of the Amazonas) which represent distinctive tectonic compartments, with distinctive geomorphological characteristics, believed to have influenced the evolutionary history of Amazonian organisms (Rossetti et al. 2005). These findings are of vital importance to region-wide control efforts currently underway among Amazonian countries to try to reduce malaria transmission.

\section{ACKNOWLEDGMENTS}

To Dr Wanderli Pedro Tadei (Inpa, Manaus, AM, Brazil) and Dr Fátima dos Santos (Porto Velho, RO, Brazil) for providing logistical support to collect the mosquitoes in the states of Amazonas and Rondônia, respectively. To Funasa's team from 
states of Acre, Amazonas, and Rondônia for providing logistic support to collect in all localities. To Drs Tomas Hrbek and Izeni Farias (Ufam, Manaus, AM, Brazil) for help with the statistical analysis. All of the DNA from the samples of An. darlingi was returned to Inpa, where it is being maintained at $-80^{\circ} \mathrm{C}$.

\section{REFERENCES}

Charlwood JD 1996. Biological variation in Anopheles darlingi Root. Mem Inst Oswaldo Cruz 91: 391-398.

Conn JE, Bollback JP, Onyabe DY, Robinson TN, Wilkerson RC, Póvoa MM 2001. Isolation of polymorphism microsatellite markers from the malaria vector Anopheles darlingi. Mol Ecol Notes 1: 223-225.

Conn JE, Vineis JH, Bollback JP, Onyabe DY, Wilkerson RC, Póvoa MM 2006. Population structure of the malaria vector Anopheles darlingi in an endemic region of eastern Amazonian Brazil. Am J Trop Med Hyg 74: 798-806.

Coura, JR, Suárez-Mutis M, Ladeia-Andrade S 2006. A new challenge for malaria control in Brazil: asymptomatic Plasmodium infection - A Review. Mem Inst Oswaldo Cruz 101: 229-237.

Deane LM, Causey OR, Deane MP 1948. Notas sobre a distribuição e a biologia dos Anofelinos das regiões Nordestina e Amazônica do Brasil. Rev Serv Esp Saúde Pública 4: 827-965.

Donnelly MJ, Simard F, Lehmann T 2002. Evolutionary studies of malaria vectors. Trends Parasitol 18: 75-80.

Excoffier L, Laval G, Schneider S 2006. An integrated software package for population genetics data analysis, version 3.01. Computational and Molecular Population Genetics Lab. Institute of Zoology, University of Berne, Switzerland.

Faran ME, Linthicum KJ 1981. A handbook of the Amazonian species of Anopheles (Nyssorhynchus) (Diptera: Culicidae). Mosq Syst 13: 1-81.

Freitas-Sibajev MGR, Conn J, Mitchell SE, Cockburn AF, Seawright JA, Momen H 1995. Mitochondrial DNA and morphological analyses of Anopheles darlingi populations from Brazil (Diptera: Culicidae). Mosq Syst 27: 78-99.

Funasa-Fundação Nacional de Saúde 2002. Vigilância epidemiológica. Plano de intensificação das ações de controle da malária na Amazônia Legal - PIACM, Ministério da Saúde, Brasília, DF.

Gaggiotti OE, Lange O, Rassmann K, Gliddon C 1999. A comparison of two indirect methods for estimating average levels of gene flow using microsatellite data. Mol Ecol 8: 1513-1520.

Gil LH, Alves FP, Zieler H, Salcedo JM, Durlacher RR, Cunha RP, Tada MS, Camargo LM, Camargo EP, Pereira-da-Silva LH 2003. Seasonal malaria transmission and variation of anopheline density in two distinct endemic areas in the Brazilian Amazon. J Med Entomol 40: 636-641.

González R, Wikerson R, Suárez MF, García F, Gallego G, Cárdenas H, Posso CE, Duque MC 2007. A population genetics study of Anopheles darlingi (Diptera: Culicidae) from Colombia based on random amplified polymorphic DNApolymerase chain reaction and amplified fragment length polymorphism markers. Mem Inst Oswaldo Cruz 102: in press.

Holm S 1979. A simple sequential rejective multiple test procedure. Scandinavian J Statistics 6: 65-70.

Kamau L, Mukabana WR, Hawley WA, Lehmann T, Irungu LW,
Orago ASS, Collins FH 1999. Analysis of genetic variability in Anopheles arabiensis and Anopheles gambiae using microsatellite loci. Insect Mol Biol 8: 287-297.

Kreutzer RD, Kitzmiller JB, Ferreira E 1972. Inversion polymorphism in the salivary gland chromosomes of Anopheles darlingi Root. Mosq News 32: 555-565.

Lehmann T, Besansky NJ, Hawley WA, Fahey TG, Kamau L, Collins FH 1997. Microgeographic structure of Anopheles gambiae in western Kenya based on mtDNA and microsatellite loci. Mol Ecol 6: 243-253.

Linthicum KJ 1988. A revision of the Argyritarsis Section of the subgenus Nyssorhynchus of Anopheles (Diptera: Culicidae). Mosq Syst 20: 101-271.

Malafronte RS, Marrelli MT, Marinotti O 1999. Analysis of ITS2 DNA sequences from Brazilian Anopheles darlingi (Diptera: Culicidae). J Med Entomol 36: 631-634.

Manguin S, Wilkerson RC, Conn JE, Rubio-Palis Y, Danoff-Burg JA, Roberts, D 1999. Population structure of the primary malaria vector in South America, Anopheles darlingi, using isozyme, random amplified polymorphic DNA, internal transcribed spacer 2, and morphologic markers. Am J Trop Med Hyg 60: 364-376.

MS-Ministério da Saúde 2003. Secretaria de Vigilância em Saúde. Boletim Epidemiológico da Malária, Número 1, Brasília.

Mirabello L, Conn JE 2006. Molecular population genetics of the malaria vector Anopheles darlingi in Central and South America. Heredity 96: 311-321.

Molina-Cruz A, de Mérida AMP, Millis K, Rodriguez F, Schoua C, Yurrita MM, Molina E, Palmieri M, Black WC 2004. Gene flow among Anopheles albimanus populations in Central America, South America, and the Caribbean assessed by microsatellites and mitochondrial DNA. Am J Trop Med Hyg 71: 350-359.

Olano V, Brochero H, Sáenz R, Quinõnes M, Molina J 2001. Mapas preliminares de la distribución de espécies Anopheles vectores de malaria en Colômbia. Biomédica 21: 402-408.

Peel D, Ovenden J, Peel S 2004. NeEstimator: software for estimating effective population size: Queensland Government, Department of Primary Industries and Fisheries.

Pinedo-Cancino V, Sheen P, Tarazona-Santos E, Oswald WE, Jeri C, Vittor AY, Patz JA, Gilman RH 2006. Limited diversity of Anopheles darlingi in the Peruvian Amazon region of Iquitos. Am J Trop Med Hyg 75: 238-245.

Rachou RG 1958. Anofelinos do Brasil: comportamento das espécies vetoras de malária. Rev Brasil Malariol Doenças Trop 2: 145-181.

Rodrigues IB, Tadei WP, Dias JMCS 1998. Studies on the Bacillus sphaericus larvicidal activity against malarial vector species in Amazonia. Mem Inst Oswaldo Cruz 93: 441-444.

Rosa-Freitas MG, Broomfield G, Priestman A, Milligan PJM, Momen H, Molyneux DH 1992. Cuticular hydrocarbons, isoenzymes and behavior of three populations of Anopheles darlingi from Brazil. J Am Mosq Control Assoc 8: 357-366.

Rossetti DF, Mann de Toledo P, Góes AM 2005. New geological framework for Western Amazonia (Brazil) and implications for biogeography and evolution. Quat Res 63: 78-89.

Rozendaal JA 1990. Observations on the distribution of anophelines in Suriname with particular reference to the 
malaria vector Anopheles darlingi. Mem Inst Oswaldo Cruz 85: 221-234.

Sambrook J, Russel D 2001. Molecular Cloning: A Laboratory Manual, Cold Spring Harbor Laboratory Press, Cold Spring Harbor, NY.

Santos JMM, Lobo JA, Tadei WP, Contel EPB 1999. Intrapopulational genetic differentiation in Anopheles $(N$.) darlingi Root, 1926 (Diptera: Culicidae) in the Amazon Region. Genet Mol Biol 22: 325-231.

Slatkin M 1987. Gene flow and the geographic structure of natural populations. Science 236: 787-792.

Steiner WWM, Narang SK, Kitzmiller JB, Swofford DL 1982. Genetic divergence and evolution in neotropical Anopheles (subgenus Nyssorhynchus). In WWM Steiner, Tabachnick WJ, Rai KS, Narang SK (eds), Recent Developments Genetics Insects Disease Vectors, Stipes, Champaign, IL, p. 523-551.

Susam/Devis-Secretaria de Saúde do Amazonas e Departamento de Vigilância em Saúde 2004. Relatório de atividades de controle de endemias, 2002 a 2004. Manaus, Amazonas.

Swofford DL 2003. PAUP*. Phylogenetic Analysis Using Parsimony ( $*$ and other methods). Version 4.0. Sinauer Associates Inc., Sunderland, MA, US.

Tadei WP 1987. Biologia de anofelinos amazônicos. XI. Estudos em populações de Anopheles e controle da malária em Ariquemes (Rondônia). Acta Amazon 17: 151-167.

Tadei WP, Santos JMM, Rabbani MG 1982. Biologia de Anofelinos Amazônicos. V. Polimorfismo cromossômico de Anopheles darlingi Root (Diptera: Culicidae). Acta Amazon 12: 353-369.
Tadei WP, Dutary-Thatcher B, Santos JMM, Scarpassa VM, Rodrigues IB, Rafael MS 1998. Ecologic observations on anopheline vectors of malaria in the Brazilian Amazon. Am J Trop Med Hyg 59: 325-335.

Vieira PP, Ferreira MU, Alecrim MG, Alecrim WD, Silva LHP, Sihuincha MM, Joy DA, Mu J, Su XZ, Zalis MG 2004. pfert Polymorphism and the spread of chloroquine resistance in Plasmodium falciparum populations across the Amazon Basin. J Infect Dis 190: 417-424.

Vittor AY, Gilman RH, Tielsch J, Glass G, Shields T, Sanches Lozano W, Pinedo Cancino V, Patz JA 2006. The effect of deforestation on the human-biting rate of Anopheles darlingi, the primary vector of falciparum malaria in the Peruvian Amazon. Am J Trop Med Hyg 74: 3-11.

Weir BS, Cockerham CC 1984. Estimating F-statistics for the analysis of population structure. Evolution 38: 1358-1370.

Wondji C, Simard F, Lehmann T, Fondjo E, Same-Ekobo A, Fontenille D 2005. Impact of insecticide-treated bed nets implementation on the genetic structure of Anopheles arabiensis in an area of irrigated rice fields in the Sahelian region of Cameroon. Mol Ecol 14: 3683-93.

WHO-World Health Organization 2005. World Malaria Report 2005. Available in http://www.rbm.who.int/wmr2005. Accessed in June 18, 2006.

Wright S 1965. The interpretation of population structure by Fstatistic with special regard to systems of mating. Evolution 19: 395-420.

Zimmerman RH, Galardo AK, Lounibos LP, Arruda ME, Wirtz R 2006. Bloodmeal hosts of Anopheles species (Diptera: Culicidae) in a malaria-endemic area of the Brazilian Amazon. $J$ Med Entomol 43: 947-956. 
